University of Michigan Law School

University of Michigan Law School Scholarship Repository

Articles

Faculty Scholarship

1916

\title{
A Definition of Consideration
}

John B. Waite

University of Michigan Law School

Available at: https://repository.law.umich.edu/articles/658

Follow this and additional works at: https://repository.law.umich.edu/articles

Part of the Contracts Commons

\section{Recommended Citation}

Waite, John B. (1912-1951). "A Definition of Consideration." Mich. L. Rev. 14, no. 7 (1916): 570-6.

This Article is brought to you for free and open access by the Faculty Scholarship at University of Michigan Law School Scholarship Repository. It has been accepted for inclusion in Articles by an authorized administrator of University of Michigan Law School Scholarship Repository. For more information, please contact mlaw.repository@umich.edu. 


\section{A DEFINITION OF CONSIDERATION.}

COMPOSING general statements of law is at best a didactic pursuit rather than a practically useful one, however agreeable an occupation it may be. The particulars of the past are not evaded by statement of their essence, and courts tend to guide their rulings by analogy to specific precedents in preference to rules educed therefrom by however studious laymen. And, on the other hand, the general expressions and definitions, so called, formulated by courts themselves, often hastily and hap-hazardly, which have been followed by other courts, do more to confuse the law, and confute its real precision of statement, than any other one factor. Comparatively little conflict exists among adjudications; most of it is between decisions and broad expression. Often when a result has been reached in the nomenclature of a particular rule, the truth is that the rule has been itself selected to fit the result desired, and terminology has been perpetuated in use where it has no real application whatever, in respect for the tenuous tradition that courts do not make law. This is undoubtedly the case in judicial findings as to consideration in contractual agreements.

From a practical standpoint there is probably no affecting of this by non-judicial generalization. But from a pedagogical point of view, definitions and generalizations may be helpful, at least, and in respect to consideration there is reason for changing the old forms. "A mild protest" has been entered against using cases, "as if they would support equally well any theory of the law which would involve the same result. Unless the ground on which the court rested the decision can first be shown to be inadequate for their support, there is no necessity or, indeed, opportunity, to seek for another basis." 1 This is undoubtedly true as a broad proposition, but in seeking a generalization of rule, perpetuation of the formal ground expressed is undesirable if such form does not cover so many cases as would another. A rule, to be exact, can be educed only from the sum total of results, not from the symbols used in reaching those results.

If "consideration" be defined in the sense of its signification and necessity, it is possible that the characteristics of its origin should be somehow included. But this is not so in defining it as to content. Such a definition is no more than a generalization of those things

${ }^{1}$ Mr. Williston in 27 Harvard Law Review, 512. 
which come within the judicial application of the term. No one has yet demonstrated so clear and precise an origin of it as to limit its application other than subjectively, and no particular terminology is of original propriety. The customary words of value or detriment have no intrinsic or vested right to use. If Mr. Hol,Mrs' suggestion be true, ${ }^{2}$ that consideration is a development of the quid pro quo of debt, it is exchange of tangible property which is of the essence. But when the courts departed from the tangibility of consideration and recognized an act and even a mere reciprocal obligation, or promise as the reader may choose, as a sufficient consideration, they eliminated all logical necessity for retaining the idea of exchange in a generalization. If on the other hand, we assume that our modern law of contract grew out of assumpsit, and that the necessity of consideration followed the analogy of assumpsit to debt, or that it was an unique development, there is still no such definite preconception of what ought to constitute the necessary vestment for enforceability as to give descriptive appropriateness to any particular word or phrase, however much one may have been perpetuated in use.

Under any theory, there has been an illogical evolution away from original form, and the general expression of consideration has been free to develop in correlation. Mr. BaLlantine says," "A theory of consideration is after all only a generalization of the cases and the policy of the law,-(and) we should modify our theory and even our habitual terminology to fit the facts." He, himself, finds the basic reason why the law refuses to enforce a "one sided or gratuitous promise" yet does enforce a "two-sided bargain" to be mere public policy based on necessity of reliability in promises whose fairness is evidenced by mutuality. As LANGDELL, departed from the established idea of benefit to promisor and defined consideration as detriment to the promisee, pointing out that it had changed its meaning from the quid pro quo necessary to create a debt to the something necessary to support an assumpsit, so AMrs progressed to "any act or forbearance or promise." of any primordial theory of the true constituent of consideration, it is as unnecessary as it is futile to attempt to reduce all consideration to the terminology of value, and equally unnecessary to relate it to the quid pro quo idea of exchange. That form of expression is both permissible and proper which best. presents the pragmatic truth found in the adjudications.

\footnotetext{
2 The Common Law, p. 258.

${ }_{28} 8$ Harvard Law Review, I2x.

4 I2 Harvard Law Review, 515, 516.
} 
By these, consideration has not been limited to real value nor to real detriment, even though words of value and detriment are usual. "Whatever a promisor chooses to accept as the consideration of his promise, the law will regard as equal to the promise in value, provided the law can see that it has any value." There is to be sure the exception to this that in cases of immediate exchange of money for money the courts have evaluated the consideration; but this is an exception-since never logically distinguished-to every definition.

Neither have adjudications limited consideration to something tangible. The doing of an act, however futile and barren of apparently valuable result, the mere making of a promise may be sufficient. $^{.}$It may fairly be said, therefore, that any course of conduct whatever on the part of the promisee is-sufficient to constitute a consideration.

The use of words of value or detriment in a definition is not only unnecessary; it is, for clarity, undesirable. Such a definition can not, certainly, conform to LEIBNITZ's description of a distinct idea as one containing nothing which is not clearly apprehended, since it is only by the baldest of fictions that certain recognized considerations can be brought within its scope. It becomes necessary to create a "value in law" as distinct from the ordinary acceptation of "value," and to say that the mere fact of a promisor's desiring a thing or an act gives it to him a value recognized by the law though not by the usage of the laity. If "detriment" be used, it is imperative to recognize a "legal detriment" in what to lay opinion would be of no effect at all, or might even be a positive benefit. The cases in which the promisee has given consideration by forbearance from conduct deleterious to himself, and the several discussions as to why a counter promise constitutes a consideration are demonstrative of this. It is true that any course of conduct can be reduced to an act or a forbearance, the words used in Mr. AMEs' definition. But "act or forbearance" is not, on the other hand, more restrictive than "any course of conduct," and since clarity is a prime requisite of a good definition, the simplest form of statement is surely the preferable, and nothing could be less susceptible of doubt than the latter.

But while any course of conduct may be a consideration, not every course of conduct does become one. There must be a certain relationship of the parties. This is usually expressed by some phrasing

s Langdell, Contracts, p. $7 \mathrm{r}$.

- Mr. Williston, writing in 27 Frarvard Law Review, 503, restricts the effect as consideration to certain promises only, but does not attempt to reduce such promises to value or detriment. He apparently recognizes the promises themselves as considera. tion. Such is the holding in Gution v. Marcus, 165 Mass. 335 . 
of exchange, e. g. Mr. Amss" "Given in exchange for the promise of another." Undoubtedly this expression, as technically interpreted, includes all admitted considerations and excludes all others. But here again there is an element of unusualness in the use of "exchange." It, and the word "given," both convey, in normal use, an idea of change of possession. Thus, the Century Dictionary in defining "exchange" uses such phrases as "to part with," "transfer," "to give and take." "Gift" is of course imbued with the necessity of change of possession for its existence. As Lord EsHER said in Cochrane v. Moore," "one can not give, according to the ordinary" meaning of the word, without giving; the other can not accept then and there such a giving without then and there receiving the thing given." It follows, therefore, that "exchange" can hardly be used, within the accepted lay meaning, of those considerations which are not possible of possession, mentally or otherwise, and which do not even result in the eventual acquisition of something by the promisor -a forbearance or promise to forbear from the use of tobacco, for instance.

There is, of course, a common use of "exchange," and perhaps of "give," in which possession is not involved, as in the phrase "an exchange of vows." This is the essence of the definition "to communicate mentally." But in such use there is invariably present the sug-. gestion of an actual, not theoretical, reciprocity of mental state. It requires a coincidence of apparent intent. But there have been many considerations recognized by the courts which are neither possible of possession nor have transpired under such circumstances as to reveal a real reciprocity of thought with the promisor, a metaphorical exchange, in any sense. In the case, for instance, of publication of a promise of reward for the doing of an act, it is held that the contract is complete upon the doing of the act. But it can not be said that there is any reciprocity of intent such as would possibly make the promise an "exchange" for the act. The promise may have been made long before and the mental attitude of the promisor in making it have disappeared completely at the time of the doing of the act. 'There has been indisputable evidence of this alteration of mental state in numerous cases in which the courts have nevertheless held a contract to have been created, through some particular person having become entitled to the reward. Such change is often found, also, in contracts created by letter. In Byrne v. Van Tienhoven, ${ }^{8}$ for instance, the promisor had so effectively changed his mind that he

\footnotetext{
${ }^{7} 25$ Q. B. D. 57.
}

${ }^{8} 5$ C. P. Div. 344 . 
had written a withdrawal of the offer before the consideration-embodied in the acceptance-had been rendered. Nevertheless the court held, on principles of justice and "practical convenience," that a contract had been effected. In Nyulasy v. Rowan, ${ }^{9}$ the promisor asserted that at the time the consideration was created he "had changed his mind." The court nevertheless enforced the promise, not on the ground that his mental intent was actually still the same, but that the offer was considered "in law" as having continued till acceptance. In: no way but that of a technical legal usage can such transactions, each individually performed, with nothing of mutuality or reciprocal mental state, be called an "exchange."

In all these cases, however, it can be said, without fiction, that the conduct constituting the consideration was induced by the promise. There are instances of contracts recognized, to be sure, in which this can not be said; such are the cases of Williams v. Carzardine ${ }^{10}$, and Gibbons v. Proctor, ${ }^{11}$ in which the promise was enforced although he who gave the consideration did not even know of the - promise. These cases can be considered only as particular adjudications outside the scope of any generalization. But except for such as these, it can be said with the utmost logic and precision that everything which has sufficed for consideration has been induced by the promise.

There is a type of cases, always extremely difficult of logical explanation, in which a certain course of conduct has been followed by a promisee at the express request of the promisor but without making the promise enforceable. Stuch is the case of Rose v. Oliver. ${ }^{12}$ Refusal to enforce the promise was put upon the ground of lack of "mutuality," that the promisee had never bound himself to do anything, although he had in fact done what was desired. These cases, when based on such ground, come into inexplicable conflict with that great body of others in which performance has been held consideration without any indication whatsoever of "acceptance" or undertaking to perform. ${ }^{13}$ In many of the former type, however, it is reasonably evident that the true ground for a denial of contract is that the performance was not induced by the promise but flowed from other motive; in other words, that there was no consideration. ${ }^{14}$

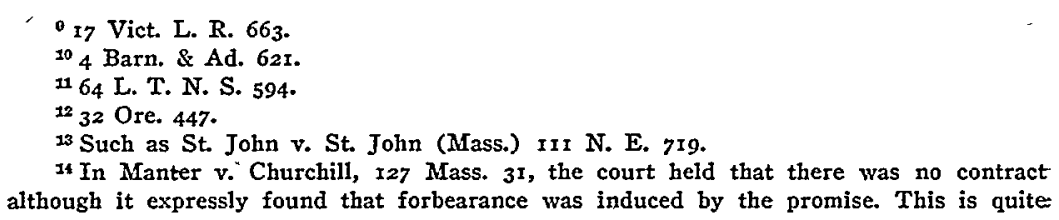


This is quite as clearly-more clearly, in fact - explained by saying that the action was not induced by the promise as by saying that it was not given in exchange. ${ }^{15}$ The frequent statement that the doing of what one is already legally bound to do is not a consideration, is no more clearly explained by saying that the act is not an exchange than by holding it not to have been induced by the promise. The latter at least affords a logical reason for the statement. ${ }^{15 a}$

But to say that every course of conduct which has been induced by the promise is a consideration would still be much too broad. There must be the assent, as Mr. LANGDELr, points out, of the promisor to it, his acceptance of it as consideration. But this acceptance may be in advance as well as after its presentation, and it may be express as well as implied. Many acts might be done in reliance upon a promise which would not make the promise enforceable.- As Mr. LANGDELL puts it, "In many cases the act alleged to be the consideration may be performed without the participation or knowledge of the promisor, even when it inures to his benefit; and when it does not inure to his benefit, of course he is naturally a mere stranger to it. In all such cases, therefore, the consent of the promisor must be proved as an independent fact. *** Thus the original offer must, to be complete, specify the consideration as well as the promise, either expressly or by implication."

So, if A having otherwise gratuitously promised $B$ a sum of money, $B$ should make expenditures of his own on the expectancy of the gift, there would be no contract. ${ }^{16}$ But if it could be made to. appear from the attendant circumstances that $A$ had in fact intended: $B$ to make such expenditures upon the faith of the promise, the promise would without doubt be enforceable. ${ }^{17}$ The fact that the particular conduct was actually within the intent of the promisoramounts to an implied acceptance of it, in advance, as consideration; to the implied specification required by LANGDELI.

This clarifies another difference in types of cases the reason for which is difficult of explanation under the accepted definitions. Thus if $A$ offers to pay to $B$ a certain sum of money if $B$ will sell to him certain property, it is uniformly held that B's promise to transfer the title, regardless of actual transference, constitutes a contract. But

\footnotetext{
out of harmony with other cases, and in Mecorney v. Stanley, 8 Cush. 85 , on which it relies, the forbearance was clearly in no way induced by the promise.

15 There is considerable conflict with this, however, as in Maddison v. Alderson, 8 . App. Cas. 467 .

153 See 14 Mrich. Law Rev. 480.

${ }^{16}$ Hollins v. Hubbard, 165 N. Y. 534.

17 Hughes v. Lansing, 34 Ore. 118, 75 Am. St. Rep. 574.
} 
in case a reward is promised for the doing of a certain act, a mere promise to perform the thing requested does not constitute a contract; the offer may be revoked up to the moment of complete performance. ${ }^{18}$ The only practical distinction appears to be that in the first case all the promisor desired was the offeree's counter-promise to transfer the title, while in the other case he wanted more than the promise to perform or to stand responsible in damages for failure to perform; he wanted the thing done, not an agreement. - In the . one he contemplated a bilateral contract, in the other a unilateral one only. In each case, however, there is a promise given in exchange for a promise, and there should, by the definitions employing "exchangé," be a contract, unless the meaning of "exchange" be here as much restricted and specialized as it is in other instances broadened. But if consideration be defined with an idea of accord with the intent of the promisor, there is then a definitive distinction between the cases, since one course of conduct accords with the promisor's intent and the other does not.

This covers also, without an interpretation of "exchange," the distinction pointed out by Mr. LANGDELL ${ }^{10}$ between those acts whose performance is a condition precedent to recovery, but in itself a consideration, and those precisely similar ones which are consideration. The former are strictly excluded, by the definition suggested, on the fact that they were not intended to be induced by the promise. The .case of Kirksey v. Kirksey ${ }^{20}$ is a good illustration of the relation which the intent of the promisor bears to the effect of acts done as consideration or as mere performance of conditions.

If then consideration be defined as any course of conduct induced by the promise and in accord with the apparent intent of the promisor in making the promise, it excludes all cases properly to be excluded and includes all others, with less abnormal use of terms than is necessitated by the definitions now generally accepted. To one who is sufficiently acquainted with the particular cases to interpret technically the language of a definition, it is not more precise than are they; but for such a one, no definition is necessary at all. It is the one unfamiliar with the cases who has need of a generalization, and for him the language from which a correct application can be most simply and normally deduced is the most precise and desirable.

- University of Michigan Lare School. JOHN BARKER WAITE.

\footnotetext{
18 Biggers v. Owen, 79 Ga. 658; Harsen v. Pike, 16 Ind. I40; Cummings v. Gann, 52 Pa. 484; Vigo Agricultural Society v. Brumfiel, 102 Ind. 146; Langdell, p. 3.

19 Contracts, p. 83 .
8 Ala. I3I. See also, Bibb v. Freeman, 59 Ala. 6r2.
} 